\title{
植物のケミカルコントロール
}

\author{
出席 者 (五十音順) \\ 倉 石晉 (東京大学教養学部) \\ 杉頉 夫(農林省農林水産技術会議事務局) \\ 田村三郎 (東京大学農学部) \\ 山田登（農林省農業技術研究所）
}

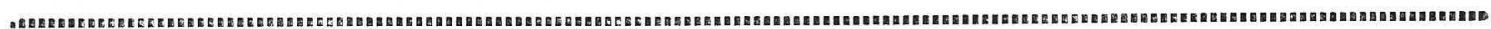

田村 近ごろ，農業の分野でケ ミカルコントロールといら言葉が盛 几に使わ机ています。しかし，その 内容が具体的にどのよらなものであ るかといらことについては，必ずし もまだ明確になっていないように思 います、きょらの座談会のテーマは, 「植物のケミカルコントロール」と いうことですけれども，この座談会 を害り多いものにするためには，少 なくともここに集まった 4 人の間で は，その概念をあらかじめはっきり さ让ておく必要があるのじゃないで しょうか.

\section{植物のケミカルコント ロールとは何か}

田村 屯ず皮切りに, 農業の分 野における植物のケミカルコントロ 一タとは何かという点について，私 の考えを皆さんに申しあげ，それに 刘して皆さんから批判や意見を出し ていただいて，その辺から問題を掘 り下げていったらと思います。

第 2 次大戦後に拈ける有機農薬の 癹達は，非常に目ざましいものがあ り，それによってわが国の農業は年 作豊作を続けている.これらの殺虫 剂，殺菌剂，あるいは除草剂をとっ てみると，すべてが化学薬剂であり， しかもそれらによって各種の生物の 生充を制御するおけだから，農薬の 伐用は，とりもなおさず農業生物の ケミカルコントロールといらことに なると思う。しかし, もう少し立ら
入って考えてみると, これらの薬剤 の生物にもたらす効果は，いずれの 場合にも，生物現象の極限状態であ る死といら現象である。しかも, そ れらの農薬は，作物に影響を及ぽし てはならないといらことが強く要求 されている。作物に対する害作用が あるかないかが，それぞれの震薬の 実用性を決定する重要な因子になっ ている，要するに，従来の農薬の農 業の中で果たす役割は, 除草剂も含 めて，あくまで作物の生育環境を整 備するということにあると思う。こ れに対して，私たらが今後発展させ ていこうとしている植物のろミカル コントロールは，作物それ自体の生 育を化学薬剤によって制御すること を主要な内容としている。もちろん， ここにいら制御は，生長の抑制ばか りでなくて, 当然促進ということも 含み，そのほか開花，休眠の調整な どきわめて多面的な意味をもってい ると考えます。

元来, 植物のケミカルコントロー ルといらと, 当然除草剂もその対象 になるわけです. しかし私たちのこ れからの活動分野を規定する場合に は，一応除草剂との関連を切り離し て考光たほらがよいのではないでし ょらか、したがって, 植物のケミカ ルコントロールといらよりも, 作物 のケミカルコントロールといった活 らがむしろ適切だと思ら。もちろん それは，本質的には植物のケミカル コントロールであることはいらまで もないが.
私としては，ケミカルコントロー ルの内容をいままで述べたよらなる のと考えたいと思っていますが，は たしてこの定義でいいかどらかとい。 らことと同時に，現在の時点で，あ るいは将来のわが国の農業政策を考

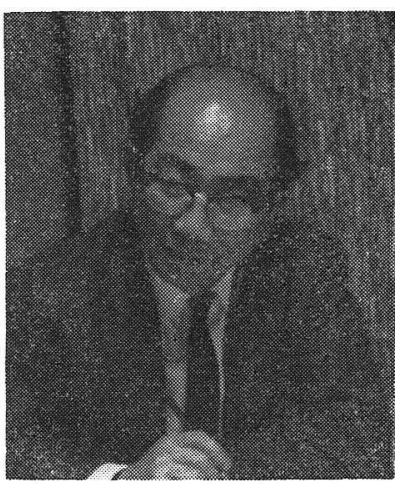

(田村 三郎氏)

えた場合に，作物の一一あ壳て作物 といいますけれども一ろミカルコ ントロールは，一体，どういら意義 をもっているのか，あるいは，どら いう位置を占めるのかといったこと について，まず杉さんから，就考党 を述べていただけたらと思います。

\section{果樹や林木あ対象} として考えよう

杉いま田村先生がいわれた， 植物ということではなくて，作物の 生育を促進したり，抑制したりする という意味でケミカルコントロー ルという言葉を使いたいということ 
には，私も同感です、植物というこ とになると, どうしても, 雑草だっ て植物ではないかといらことになる。 ところが，われわれが対象として考

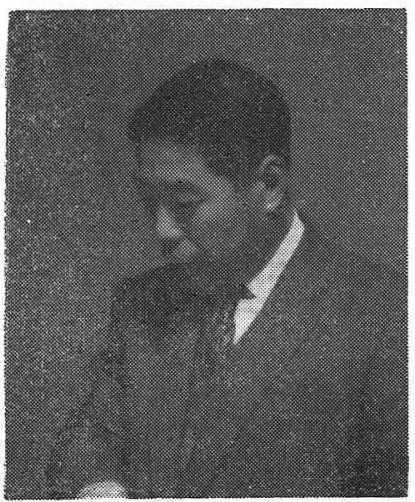

（杉 穎夫氏）

えたいのは，あくまでも農梷生産物 として直接人間が必要としているも のであるから，同じ植物であっても 雑草は農業生産物とは考えられない わけです. そこで，当然作物という ことになってくるけれども，作物と いらと， 1, 2 年生の作物といった 感じがはいってきて, 桑とか林木と かいらものはだいぶ離れた感じがす る・しかし最近では林業もだんだん 集約的になっている。したがって， 果樹とか茶樹などをも含めて，一般 以農業生産物, 農林生産物を対象に することで，原則的にはとれでいい そ思います。

従来, 作物そのものの性質を变え る手段としては, 品種改良と肥培管 理の 2 つの面があった。このような 方法で生育期間を伸縮することは, ある範团内でできますが，農業が進 歩してくると, 人間の欲望も多くな ってきますし, 従来の技術, 手段で は突破できないものが出てくる.そ れを何か別の手段でもって，作物そ れ自体に作用を与之, 従来の技術に よる改良の範囲を大幅に越えた何か をやらなければならないといら気運 が出てくるのは, むしろ当然と思い के。

とくに最近は農業の機械化がやか ましくいわれていますけれども，そ れにらまく合うように作物の汪うも 変わっていかなければならない面が
あります、実際に、機械の汪らから 作物に合わせるといっても，それに は自ずから限度があって，一切機械 に抎んぶするわけにはいかないとい うことになると，作物に対して機械 にらまく合うような生育をとらせる 方法を講じなければならない。とこ ろが, 従来の品種改良なり, あるい は普通の耕種肥培管理の技術の範囲 では, とても間に合わない面が出て くる.そのような場面にケミカルコ ンらロールを考えたくなるといらこ とです，農業生産の立場からは，そ ういう意味でみているわけです。

田村山田さん, 実際に官庁の 試験研究機関でお仕事をなさってい る立場から,ヶミカルコントロール の意味といらか, あるいは，過去に はこらいら実績があったとか，今後 はこうもっていきたいというような ことについて，何かお考党があれば …..

\section{農業の機械化とは}

\section{車の両輪}

山田農業上の意義については, いま杉さんがお話になったことで尽 きていると思う、私もまったく同感 で，今後の技術の進歩をささえるも のとしては，人間の手に代わるべき ものとして機械を導入して, 労働の 生産性を高めていかなければならぬ といらことが1つの大きな柱になる。 けれども，その際に，それと車の両 輪のような形で，機械に合った形の 作物を作っていくことは, そう容易 にできないから，ここで化学的な薬 剤の活用をはかっていくといら場面 が, 非常に重要な問題になってくる 之思う。

その顕著な例としては,アメリカ の棉栽培に拈ける脱葉剤(defoliant) の利用がある.アメリカの棉の栽培 をやっているところでは, 従来, メ キシコ人とか黑人の農業労働者を使 って収穫期に綿の摘採をやっていた がだんだんそれを機械化してきた。 機械で綿を収穫するときに，葉が作 物体上に付いていると，それが綿の 繊維と一緒に機械に吸い込まれて，
詰まってしまったり，繊維の品質を 痛めたりといらことがおきた。それ で，機械で綿を収穫する直前に葉を みな落としてしまうという目的で， 脱葉剤を利用する. 普通使っている のは, 塩素酸マグネシウム, 塩素酸 ソーダ，エンドサル (endothal) な ぞで，そらいう脱葉剤が開発されて きて, 初めて綿の収檴の機械化が本 格的なものになったといえる。

これは, 機械化とケミカルコント ロールが車の両輪のごとく, 農業の

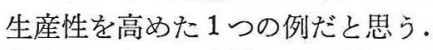
従来は, 水のかけ引きや肥料のやり 方という, 篤農的な肥培管理によっ て作物を人間の望ましい形に育てる ように努めているけれども，それに は一定の限度がある. その限度を打 ら破って, やはり新しい面を開いて いく必要がある. そのためには物質 のもっている生物学的な活性を利用 して, 従来できなかった新しいこと をやっていこらといらことが, 将来 の1つの大さな方向になっていくの ではないかと思います。

\section{閣 ケミカルコントロールは 日本の農業の現実に 根ざしている}

田村私の個人的な考えかもし れないが，われわれがいまここで問 題にしている作物のケミカルコント ロールは, かなり日本的な意味を含 んでいるのではないでしょらか。た とえばわが国では, 土地改良は大体 済んだ, 灌溉, 排水施設も大体完備 した，肥料の供給は十分だ，農薬も すでに過剩生産である.このよらに 土地条件，あるいは農業資材が完全 に確保され, その上にたって収量を 上げ，あるいは，労衝力を節約する ためにはぞうすればよいかといら， ある程度前提条件がみたされた上で われわれは問題を考えているのじゃ ないだろらか，その点で，わが国の 集約農業と, 考方方のうえでも, 㐫 るいは現実のらえでも，密接な関係 があるよらに思ら。

しばらく前にソ連のフルシチョフ が彼の演説のなかでン連農業の化学 
化といったとき，わが国のある人は わ礼和が考克ている化学化とは， まさにそれに相当するものだといっ たことがあるけれど，私はこれは䛊 りだと思う。なぜかといらと、りビ エト農業の場合には, 処女地の開拓 を含めて，むちゃな粗放農業を行な つ大結果, その技術的欠陌が現在一 番集中的に, から特徴的に現われて きたのが肥料の欠乏である.フルシ チョフのいっている化学化は, るっ と畑の中に肥料を入れろという意味 の化学化で, その点でわれわれが現 在の段階で考光ている化学化とは何 十年もの差があると思いをす。空れ を同じよらにみるのは，卒直にいら と見かたが甘すぎるし，また現在の 時点に批いてケミカルコントロール

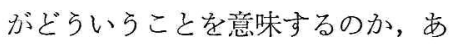
るいはわが国の風土の中でどらいう 意義をもっているのかといらことに ついて，考方方が少し見当はずれで はないか。

その日本的といら意味に执いては， たと党ば，今後ケミカルコントロー ルが適用される主要な場面としての 水田などでも，いるいろ問題がある のではないでしょうか。

\section{労㗢力の不足からも}

\section{開発を迫られる}

杉私はこう思います、いろい ろな条件が满ち足りたらえで，何か さらにそれらをよくするといらこと と少し違らのですが，実は労㗢力な んか満ら足りるどころか，むしろ 逆になってきています。たとえば， リンゴの花や奏がよけいつきすきるる といいリンゴができないから，実に ならないららに花を間引き—園芸 で摘花といいますが一する。こ れは機械でやららと思ってもちょっ とできない。らつう, 農業で機械化 というと, 人問の手労㗢を機峨侐 さ换光ることだと考光られがちです が, 機浌化とは, 手労㗢でできない, 少なくとも非常にやりにくいことが やれるということが，活んとうだと 思います、リンゴの摘花の場合には， とても機峨でけ「手」に負光ないの
で，人手に頼るほかない，たた，貴 重な労働力をそういうことに使って いては生産費が上がってどうにもな らんということで，薬剤を散布して 摘花することがすでにある程度実用 化しています。

山田果樹園の経営規模の限定 要因は, 摘花, 摘果㴗する学動力 にかかっているといわれている。そ れがネックになっている.

杉労衝力がたいへん不足して いるからななとか人手を省きたい， しかし，省きっ放しにして批ば生 産そのものがだめになるので，何か で肩がわりしょうという場面に, ケ ミカルコントロールが登場してくる.

\section{発芽, 分けつ, 倒伏- 水田にも問題は山䅣み}

山田きょらの和話は除草剂を 除くことになりますが，水田に扮け る除草剂利用の最近の伸びは, その ベックになっているのが労㗢力の不 足ですね. 水田の卧らで，さしあた ってどういら問題があるかといらと， 話題を提供するという意味でいくつ か羅列してみると, まず最初, 来か ぬ夕ネは生えないし，まいた夕礼 生充ないというのでは困るから，水 稻の直播栽培をやっていく場合に, 一番問題になるのは発芽だと思う。

移植を中心とする従来のわが国の稻 作では，農家が発芽に対しては，万 全の手だてを尽くした。てい放いた 苗代を作ったり，温度が低的ればビ ニールをかけて保温したり, 水のか け引きに気を使ったり，いろいろ発

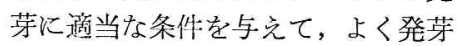
させるといらことをやってきたから， 不良環境で発芽がうまくいかないと いうことは, あまり問題にならなか った。ところが直播きになると，そ こで一度失敗すれば, 広い本田でも ら一度やり直さなければならぬとい らたいいんなことになりますし，ま いた種粐が雨にたたかれ，あるいは 水分欠乏にもあらだろらし，いろい ろ不良環境にあう。そういらところ を早く発芽させて, 早くスタンドを 作ることが問題になってくる.した

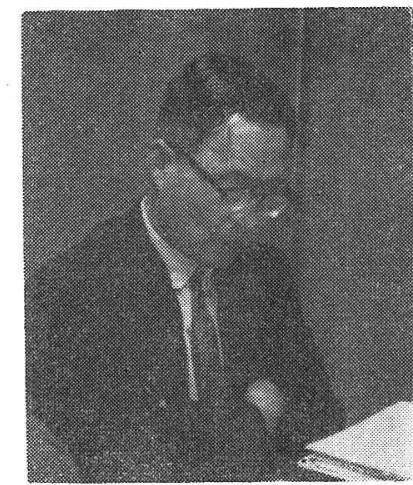

(山田 登辰)

がって,なんとか早く発芽させるこ と,すなわち発芽の促進, これが今 日のいわゆるらミカルコントロール の, まず第 1 の㟪題に取りあげられ。 るべきものだと私は考员ます。

第 2 の問題は分けつの調節がある と思う、発芽がそうらように手を加 えても，発芽歩合が比較的低いこと を見越して種粐を索いたところが， それが全部発芽してしまって，たい。 へんな厚播きになることも亦るだる。 ら。薄播きにすぎた場合，発芽步合 が低いときには，ただちにたくさん， 分けつさせて, 荃数を確保しなけれ

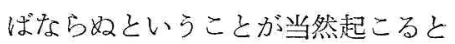
思う、金のかからない方法で適当な 分けつ数劣確保することが, 最後の 収量を確保するら元に大事な問題に なってくるから，いかにして分けっ 数をふやすか, あるいは, 減らすか という, 分けり数のレギュレーショ ンが第2のケミカルコントロールの 問題になるだろうと思います。

第 3 の問題点は倒伏防止ですね. これは, 機峨化, ヌンバインで収穫 をしていこうということになると， 倒れてしまったるのでは能率が悪く なる。しかも，直播さの稻はよけい 倒伏しやすいから，これを防がなけ ればならない，その場合には品種の 選択, 肥料のやり方歹考党なけ虬ば ならないが, それでもな和から倒れ るものな防ぐ方法があるかどらかと いら問題です㸚。 


\section{収量の增大も}

\section{考えられる}

山田 その次の問題は，これは 別值播き, 移植に限りませんが， たとえば 10 アール当り $600 \mathrm{~kg}$ と れる，あるいはへクタール当り 6 卜 ンとれるという稲の最後の収量は, いつごろ作られるかといらことです が，従来の研究によりますと，大体 玄米収量の 20 ３0\% にあたる部分 のものは, 穂の出る前に作られてい る. すなわち, 最後の収量の $20 \sim 30$ \% は穂の出る前に作られた澱粉で ある。そしてその残りの 70～80\% 近くの澱粉は，穂が出てからあとで 作られるものなのです。ところが， 従来の栽培法をみると, 出穗以前の 時期には, 中ぼしをするとか, 除草 をするとか，穂肥を施すとか，いろ いろと手を加光ますが，穂が出てし まってからは手を加光る技術がない， 出穂が近づけば，村祭りでもやって あとは収穫を待つということなんで すね。もっとも，たとえば中ぼしに しても，根の生理的活力を高く維持 させて，穂が出てからあとも，な㧊 かつ植物体の栄養をささえるような 状態に根をもっていくということが ありますが，乙かし，作業としては， いずれも穂の出る前に終わってしま う。ところが，なんと，いま申しま したように，収量を最も大きく左右 するのは穂が出てからあとなんです。 したがって，われわれとしては，研 究の重点を穂の出る前ではなくて, 穂が出てからあとの物質生産にもっ と抒かなければならない。

たと党ば，穂が出てから粒が完全 に実るまでの期間を仮に 2 倍にのば すことができれば，収量はどうなる かといらことが当然考兄られる. 穂 の出る前に一定の葉面積を確保して おいて, 確保された一定の葉面積で 登熟期間を長くもっていけば, 当然 最後の収量は多くなるはずである。 それができるかどらかということで すね.これには，いろいろな問題が 含まれると思うが，わが国で稲を作 れば 1 年生になるけれぞも, これは
植物体が老化してしまって水分を失 って枯れていく. 菱葉の老化を化学 的物質によって执さ觉ることができ るかどうか．また一方，粒が肥大し て生長していくその期間を, 途中で 止まらないように長引かせる。その 面に 1 つの新しい研究の分野がある のではないかと思います。

田村杉さん，そのほかに農業 全般で，これはケミカルコントロー ルを考えなければならぬということ を, 農業技術の体系の中で何か........

\section{加工利用に合わせた 栽培法の開発を}

杉 夢物語に近いといわれるか も知れませんが，たくさんある。い ろいろ特話を聞いていると，早い話， なんでもケミカルコントロールで片 づくような気がして困りますけれど も，たと壳ば，稲とまったく違った 茶樹の上うに, 一年中葉が青く, 目 的とするものも，実でなくて葉であ るといら作物ですと，これは全然稲 と違った面も出てくる. 茶樹は, 摘 みとった葉のままでは，何の商品価 值のないものですね。その生葉をわ れわれが特茶として飲めるようにし て, 初めて商品, 嗜好品としての 「茶」になる。このように，烟にあ る茶樹の葉は, 製茶工場と関連づけ て考党ているから，工場の製茶工程 と結びついた茶葉の生産をどうする かといら問題が必ず起こってきます。

製茶工場は静岡県や鹿児島県その 活かにもたくさんありますが，年間 の稼動日数は 25 日位から 40 日位, あとは遊んでいるわけです。しかも， 茶の葉は, 一番茶, 二番茶, 三番茶 そいららうに摘も時期によって品質 が違って，玉露などは一番茶の一番 いいところですね.ところが最近は， この扮茶摘みの時期になかなか人が 集まらなくなってきました。また， 別の見かたからすれば，いまのとこ ろ, 製茶工場の操業が一度にかたま るようなお茶の摘及方をしていると もいえるわけです，それをたとえば， 10 日間位でも打茶を摘む時期を遅 らせることができれば，ピークがそ
れだけ低くなるわけで，労働力の活 らもその分だけは楽になるだろうし， 工場のほうも一度に集中しないで， 稼動日数もある程度のばすことがで きるようになると思う。こういうこ とで茶の葉の生育を少しでも遅らせ て摘採期間をのばし，ピークを崩す ような技術が非常に望まれています。

これを品種改良でやるということ になると，たと放ば茶園の品種構成 を, 早生, 中生, 晚生を適当们やれ ばいいのではないかということにも なるけれども，現在のところ，晚生 品種にはいいものがない，茶樹は永 年作物だし，いくら䪹張っても交雑 育種でやれば品種改良に 15 年か 20 年位はかかってしまう。それを待っ ているわけにはいかないわけです。 そこで，さしあたりの問題としては， 茶の摘採期を延長する有力な手段と して，何か化学物質を利用すること はできないものか．その辺が研究問 題です.

茶は稲・麦と違って嘫好领料の原 料作物ですが，わが国の特産物でも ある。とくに日本の茶は，中国とか， そのほかの国の茶と, 国際市場での 競争もあって，だんだんと労貨がュ スト高の大きな要因になって輸出に もひびくようになり，それほど楽で なくなってきた。そうなるとどこか でコストダウンをはからなければな らない．統計調査部の資料によると， 緑茶 $10 \mathrm{~kg}$ 当りの所要労力は 37 日 で, そのうち茶摘みに 22 日かかっ ている.この労力を確保するのに， その期間が短い注ど，高貨金を払わ ざるを得なくなり，ピークをくずせ ば，䢙金も低くて済むことになる。 摘むほうのコストもさることながら， 工場の稼動日数が短くて工場が効率 的に動いているとはいえないから， その面からのコストダウンもはかっ て，外国の茶に対抗することも考兄 なければなりませんね。茶という特 殊な作物 1 つをとってみても，こう いう問題があるわけです。

山田扮茶のみならず，わが国 に暖地ビートを作るにしても, 同じ ような問題はありますね。

田村 いままでの拓話で，われ 
われが指向しようとする方向が出て きた. 逆に，一体そらいらららに植 物一一今後は植物一般でいいますけ 就も一一生育なり生活現象を， 化学的な手段で, 任意にコントロー ル，必るいはレギニレートしうる可 能性があるかどらか，もしあるとす る管らば，そのアプローチの方法は どらいらものかといらことについて， 倉石さん，話していただけませんか。

\section{実験室的にはすべての} 調整が可能だが

\section{倉石作物全体定考党る場合，} ほとえどのことは, ある程度コント ロールできると思う．実際に個々の 作物について必ずできるかと問われ ると困るけれども——わわれが実 㗊室的に作りやすいものばかりや。 ているのでしょらが一現に発芽を 促進させるむのをわれわれはもって いるし，分けっ促進戍といらものを もっている。李た，倒伏防止も実験 室的には可能だし, 年齢をのばすこ とも可能だし, あるいはすた生長を 促進させることも実験室的には可能 である、ただわれわれは，実験室で 使いやすい植物で，使いやすい状態 で穾験しているから，それが茶でで きるかとか，稻でできるかとかはな だ保証できませんが，まずそういう 状態だと思います。

田村従来, 私たちが化学物質 をスクリーニングする場合，実際に はある特定の植物にそれを与えて， 植物の生長が促進されるとか, ある いは，扣さえられるとかいらことだ けを観察している。これからは, 目 的に最も適合した新しい方法をみつ けなければならないといらことです 永. その場合に，そらいらものを見 いだしていくやり方について, 具体 的にどういうことが考光られますか。

倉石 それにはやはり, バイオ アッ七イの方法が一番問題で, これ をやっていきたいと決めたときに， いきなり畑にもっていくわけにいき ませんから, 実験室でやらなければ なりません，そのためにはどらい ら工合にテストしていくかといらこ

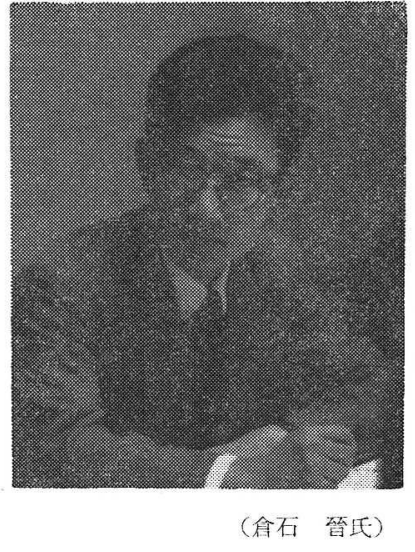

とが問題です、菖からよくやられて いる開花ホルモンで，フロリゲンと いわれるものがどうしてもみつから ないのは, 開花ホルモンを調べるた めのバイオアッセイで良いものがな いからです放. その反対が萃の伸長 促進ですが, オーキシンであれ, ジ ベレリンであれ, 良いバイオ丁ッ七 イがあるために発達した。艮い:゙イ オアッセイの開発ということを, 末 ず最初に考えなければ始まらないと いってよいでしょう．たとえば，分 けつの調節といらことに関しての良 い:イオアッセイといらものを，い まの生物学者はあまり考光ていない と思う.ともかく，良い゙イオフッ セイを開発してやってみよらといら 気持をわ秃れがもたなければなら ないし，また，るつべきなんですね。

田村確がバイオアッセイの 問題が一番重要だと思いむす。たと えばイネの倒伏防止のためには, 茎 を太く短くすることが良いと思う。 しかし，伸ばす活らのテストは割合 に簡単にできるが，奇形も作らずに 茎の生長を抑制一インヒビット (阻害)ではなく、リタード（抑制） 一するといらことをてっとり早く みきわめることは，なかなかをずか ᄂい.

しかも，ある植物を使ってテスト し，その生長が扰さえられた場合， 伋にそれがリタードであると判定で きたとしても, 最終的に収量が減っ てはどうにもなりません、私はっケ ミカルコントロールに興味をむちな がらも, 具体的な農業生座の中で役
に立ラリターダント（抑制剂）を見 いだそうと考えると、すぐにそこで 暗礁に乗り上げてしまう感じがしま す. 山田さんは, 試験研究機関でケ ミカルコントロールの研究をして拉 られるから，その上うな閭題につい $\tau \cdots \cdots$.

山田 いまのところは1年に 1 回しかホールプラントでの実験がで きない，適当なバイオアッセイがな ければ, 労働力がかかるし, 能率が 上がらないといらことになります。

杉爷こで，方法論的にホール プラントで 1 年間芑過ぎなければわ からないということでなく、生育の 初期にこれが良いとか悪いとか老七 レタトする方法が，いろいるとでき つつあると思いますけれども，上に かく最後まで見届けなくても判定が できるということにな机ば，非常に 能率が上がりますね。

山田 たとえば，分けっのコン トロールを対象とするスクリーニン グならば, 幼植物を供試して 1 年に 数回くりか学すことも可能だが，出 穂期以後の稔実期間を長くする作用 のある物質を探索するということに なると，ホールプラントをそのステ ージをで育てなければ，何ともいま のところは方法がない。

\section{ケミカルコントロールの 研究にはシツコサが 必要である 露}

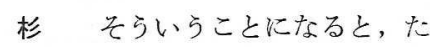
とえば作物の形態ですね. 節間短緶 をやるとなると形態もかなり変わっ てくるし，山田さんの扣話のような 物質を探索するという研究場面では， 対象とする作物の生理機能全体が, 従来はそれなりのバランスを保って いたものが，その物質の処理によ。 て, アンバランスーアンバランス といっては㤸しいけれども一の ものになるといら心配はないでしょ らか. ある化学物質を作用させるこ とによって，その目的とするものは 確かに達せられたけれども，逆に他 の実用的な特性なり, 形態なりがダ メになってしまったといらことは。 
植物学では良いにしても，作物学の 分野では困るといらようなことはな いでしょらか。

倉石 そこは植物学者の場合は 逃げてしまう．逆にそこを逃げては いけない，逃げないように拉いに やらなけ机いけないと思らんです。 こころが実際問題としては，たとえ ば細胞分裂を促進するものがあると すると，それだけで喜んでしまい， それが実際の作物にどらであろうと 関係ないといら形で逃げてしまうん で，もら少し突っ込んで最後までや らなければならぬといらことになら ないのです.そういらことは，ほと んぞ今までやられたこともなかった し，そのような必要性がいわれたこ ともないわけです。

田村 アメリカでは, CCC*や AMO-1618**などいくつかのケミカ ル・リターダントが見いだされてい ますが，それらの発見の契機はかな り偶然的なもので，それをわれわれ が一般的なスクリーニングの方法と して利用することは，汪とんどでき ないように思います。

倉石さんはアメリカに長くおられ たから，たとえば新しい作用物質を みつける場合のスクリーニングの体 制とか，それを生み出す全般的な条 件なぞについて，わが国と違ったも のを感じませんでしたか。

倉石別に違ったことは感じな いけれども，ただ私がいえることは， 前にいったことと逆のことになりま すが，たとえば CCC にしろ，オー キシンやジベレリンにしろ, 非常に 多種の生理作用をもっているから， 植物体内のどらいらことに対してで むいいから，何か影響があったとき， できるだけいろんなバイオアッセイ

* (2-Chloroethyl)trimethylammonium chloride $\mathrm{ClCH}_{2} \mathrm{CH}_{2}-\mathrm{N}^{+}\left(\mathrm{CH}_{3}\right)_{3}$

** 2-Isopropyl-4-dimethylamino-5methylphenyl-1-piperidinecarboxylate methyl chloride<smiles>Cc1cc(OC(=O)N2CCCCC2)c(C(C)C)cc1N(C)[14CH3]</smiles>

を使ってテストしてみる. 何か1つ でもとらいら作用があれば，ほかに もらんと作用があるはずである。た とえば気孔の開閉を促進させるもの があったとするならば—あるかど らか知らない壮れども一自分は気 孔の開閉の専門家ですといって終わ らないで, 茎の生長促進にはどらか とか，開花にはどらかというように， いろいろな現象について調べてみな ければならない。

それから 2 番目に大事なこととし て，ただそれをぶっかけるだけでは なくて, 基本的にもら少し下からみ てゆくことが大事だと思ら．たと立 ば植物のなかで, オーキシン, カイ ニン, ジベレリンの 3 種で植物の調 整が行なわれているとしても，この 3 つの植物体内での量を直接ないし 間接に調整してゆくことが，1つの ケミカルコントロールの大きな行き 方であると思う. その場合逆の面か らみれば, 今の植物がホルモン的に 一体どらいう状態であるかをはっき

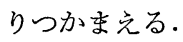

私の考えでは, CCC はオーキシ ンのレベルを下げるのですが, やっ ぱり現実の植物体について, これは オーキシン過剰である, あるいは過 少であるといらことを確かめたらえ でそそれならばこらいう薬剤を用い てみたらどらかといらことを考える 必要があると思う。ただかけただけ ではしようがない。医者が患者を診 るときに，どこが悪いからこの薬を 用いるといらことをやるのであって， それと同じことを，植物のなかでは こらなっているから，これを用いる， 与える，といらレベルまでやってゆ かなければ，ケミカルコントロール はむずかしいと思う、今までのいわ ゆるぺスティサイドは, 殺せばいい といらわけで，これは割合に楽なん ですね.ところが，こっちは医者的 な役目になるので, 基礎的ないわゆ る生長生理といわれていることをも っと深くやらなければいけない。た とえば，植物の一生をオーキシンな らオーキシンだけで追ったといら報 告はないんですね. どういう年代に なったら，オーキシンがどらなって
いるかといらことすらないわけです. オーキシンの作用をやるグループは, ずいぶん一生懸命にやっているが， ちょうど, いわゆる農学の基礎とな るべき研究がゼロなんですね. それ をぜひケミカルコントロールの研究 ではやらなければいけないと思学え です.

\section{ロ エチオレートしない 植物を対象として}

杉そうですね. 窒素, リン酸, カリなどについては, 幼植物特代か ら終着までの追跡は，ほとんど完全 にやられている作物があります。と ころが，ホルモンなどの場合，植物 の一生を通じての生育と関連づけ の経過的な追跡は，まだ行なわれて いない，花が咲く時期にはこれだけ あった，種子を播き発芽のときには これだけあった，といらことはあり ますけれども，その途中の連関がな いわ牧ですね。

山田 だから稲で株の節間が伸 長するときに，オーキシンの関係は どらなっているかといらことがわか らない.

倉石わからないといらよりも， やっている人がいないんですね. そ のレベルの仕事をやらなければいけ ないと思う。私自身は今まで生長生 理を 10 年あまりやっているけれど も, その間に一度もエチオレートし た植物を使っていない，それが私の 誇りなんですが，それは結局，ねら いは何かといえば，植物ホルモンが エチオレートした異常な状態ではな くて, 普通の植物でどらなっている かといらことを少しでも探ってゆこ ら.とれが私の一番のねらいですけ れども…..

\section{日本の植物学と農学は 互いに分離している}

田村 だいたい，日本において は, 植物学と農学との分離, 遊離を 感じますね。

會石非常に離れている。

田村 日本では植物学は農学の 
基礎であるという考え方が，植物学 者汇も農学者にも稀薄ですね. 昨年 の 8 月, エジンバラで第 10 回国際 植物学会議がありましたが，イギリ ス政府が記念切手を出すぐらいにた いへん盛会でした．私はそそれ出席 してみて，どうしてこんなに力を入 れるのかと思ったのですが，開会式 に护ける会長のあいさつにも，植物 学は農業の基礎であるということば が含まれているのです。

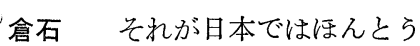
にゼロですね.アメリカでは，たと えば農学部で基礎的なことをやって いるし，植物教室でもやっている。 その間の往来は非常に自然なんです。 たとえば植物生理学会があるけれど， それをみても, 半分ぐらい農学部か らきている.けっしてその間が離れ ていない.みな一緒なんですね.と ころが，日本では植物学会があって，

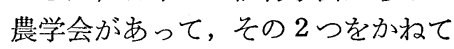
いるような学者が何人いるのでしょ らか。

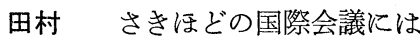
20 人位の日本人が出席していたケ れども, 要するに狭義の農学者とい ら人は, 私の知っている限り, 1 人 も参加していなかった。 ところが， イギリスにしろアメリカやオランダ にしろ, 植物生理学の分野の中心的 な人物は, 農業大学や農業試験場関 係の人が多いですね. 日本では農学 者が植物学から離れているといらこ とを痛感しました。

それと同時に，次のようなことに も気がつきました、私はケミカルコ ントロールに色気をもっていたから， 形態形成とか, フラワー・インダク ションなどの植物生理関係の部会に 出たげれど，ついにそこでは日本人 に会わなかった。日本人みたいな人 がいるなと思って, 話しかけようと 寄って行ったら，それはタイ国から きた人だった（笑). 結局, 日本の 従来の植物学者は, 最近の植物生理 学の動向についてゆこうとしている のかどうかということが $1 つ と ，$ 逆 に，ついてゆく意思のある人は植物 学の主流ではないんじゃないか，あ あいら国際会議に出席するだけの条
件に恵まれていないのではないかと いうことを感じました. 日本の農学 にはたくさん問題があるけれど, 植 物学のほうにも問題があって, 形態 とか, 分類を研究している人が実際 には学界の中心的な存在をなしてい るのではないだろらか，その点はど らでしょうか。

\section{倉石 それをいったら怒られま} すよ (笑).

\section{農業の発展には} 植物学者も必要である

田村 外国では農学関係の多く の人が植物生理学の分野で活躍して いるわけですが，杉さん，日本の農 業関係の試験研究機関をみていて, 問題を感ずる点はありませんか。

杉 学会との関係といらことも さることながら，たとえばアメリカ の例では, 州立の農業試験場がたく さんありますね。㐎らいう試験場へ 行って，そこの技師にあなたの専門 は何ですかと聞くと, 自分の専門は プラント・フィジオロジーだとか, はっきりいう、ところがわれわれの 場合, アメリカの州立農業試験場が, 国立, 県立いずれの農業試験場に相 当するかはとにかく，たとえば国立 の農業試験場へ行って同じよらなこ とを聞いても, 自分の専門は植物生 理学だといら返事はあまり聞くこと がない。

倉石 いったら, 怒られるんじ やないですか。

杉 怒られるかどうかは別とし て, そういう物の考方方が試験場の なかにあまり感じとることができな い。あるかもしれないが，きわめ て少ないか, 少なくとも, 表面に浮 かび上がっていないような気がする。 アメリカの州立農業試験場は, われ われの見聞するところによれば，相 当プラクティカルな場面を重んじる といらことだけれども, それにして もとこにはらゃんとプラント・フィ ジオロジストとか，それとは別にア グロノミストがいる. しかし, 日本 では山田さんは別として，アグロ・ ケミストという考完方が稀薄じゃな
いかと思う．日本の農業試験場のこ れからの行き方としては，そういう ことがいえるようなふんいきなり， あるいはそらいう人を養成して，プ ラント・フィジオロジストが普通の 顔をして働ける試験場になってほし い. 少なくとも国立の農業試験場之 しては, そらありたいものだと思い ますね。

\section{倉石 絶対賛成ですね}

杉 私もかつて農業試験場にし、 て，烟作物関係の仕事をしていたけ れども,たとえば生理学的な研究に タッチしていても, そこから,さら に生化学的な方面まで笑っこんでい くことがなんとなくやりにくかった しまたそういら感じを受けました 亦.

\section{■自然の法則に基づいて 農業技術は生まれる}

山田私, それについてこんな らうに考光ています，農業技術を支 配する法則性が 2 つる。これは農 業技術に限らず，実はあらゆる技術 について共通なことですが.

その 1 つは, 自然の客観的法則て すね。 それを除いて技術は成立しな い。農業技術にしても，たとえば種 子の発芽は, こらいら水分の条件, 温度の条件のときに起こるという自 然の客観的法則を, 学問的化研究し てそれを活用するか，あるいは経験 的に知ってそ机順応しているか， ぞっちかですけれども, 要するに, 播種の技術はこの自然の客観的法則 に立脚している.

しかし，技術はそれだけでなく， もう 1つの法則, すなわち最少手段 の法則によって貫かれている．最少 の生産手段, すなわち最少の人間の 労働力之最少の資源をもって, 最大 の生産を得るといらことがなければ。 技術としては成立しない。ところで, 試験場の技術研究は，いわゆる技術 組立の研究といわれる, あとのほう ばかりやっている. 自然の客観的法 則を問題にする限り, 作物自体と, それを取りまく環境と作物とのイン ターアクションを支配する法則を， 
純自然科学的にもっと明らかにして, 技術の可能性をつか及出してくる必 要がある.たくさんの新しい技術の 可能性がそこから出てくる.それが ほんとうの技術になるかどうかは， もら 1 つの最少手段の法則によって 規定される.これに合致しないもの は技術にならないということなんで すね.

自然の客観的法則に関する研究に 力を入れるのは, 試験場の仕事では ないということで，あとのほうばか り考えていたけれぞも, 自然の客観 的法則の研究が進まないから，あと の研究も進まないわけですね.

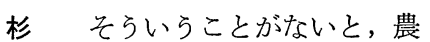
業虽新的な技術が生まれてこない。 工業のほうでは革新技術といわれる ようなものがいるいるとあげられる よらですが, 農業の分野で, これが 革新技術だといらものが，今までに ぞれほどあったか. 革新といらから には，表現としては適当でないかも 知れないが，何か非連続的な飛躍と いうものがなければ，革新技術だと いってあまり大きなことはい党ない。 そらいら意味で技術の点からいって も，化学物質による技術は，革新技 術の 1 つの根源になる萌芽的なもの じゃいかと思う。

\section{生物現象には必ず原因と なる物質が介在している}

山田倉石さんが拈っしゃった ように，1つの作物をとっても，そ のライフサイクルを通じて，オーキ シンがどうなっているかというよう な研究を進めなければならぬといら 打話がありましたが，それと同時に 私が前から考光て招りますのは，た とえば葉が落ちるときには葉を落と す物質が必ず作用しているに違いな い. 花が咲くときには必ず花を咲か せる物質があるに違いない，それは カイネチンやジベレリンとは違うも のかもしれないし, 同じものがある かもしれない.いずれにしても, 生 長, 発育などのすべての現象が, 必 ずある特定の物質で支配されている に違いない。

Vol. 3 , No. 4

(195)
たとえば，葉が落ちるという現象 についても, 葉の中のオーキシンレ ベルそ茎の中のオーキシンレベルと の相対的関係が関与し, 茎の中の才 一キシンレベルが高い場合には葉が 落ちるといわれていましたが，最近 では落ちた葉を集めてその中からあ る物質を取り出し, 落葉は落葉を起 こさせる特定の物質の存在によるの だとする報告もあります，休眠の場 合も，桃の休眠にはナリンゲニン (naringenin) が休眠物質として存 在している. 小麦種子ではカテキン タンニンが休眠物質として働いてい る. 以前にわが国でも, 発芽の早い 水稲品種と扮そい水㸺品種の両方の 種子を並べてまきますと，ちょうど 中間的な発芽をするということを岡 山大学の笠原さんが発見されました。

昔から生態学のほうでいわれてい る, シングル・スタンド—ある種 の植物が繁っている場合に, そのま わりにほかの植物がない一の現象 そついての説明として，ある毒物が 天然に生産され，それがほかの植物 の生長を阻害しているといら概念を 1830 年代にフランスのドカントル が提唱し, つづいて有名な化学者の リービッヒもその考方方をとった。 リービッヒは, しかしその後, trace element の研究を行ない, 異種植物 間では trace element に対するュン ペティションがあって，それが光や 養水分に対するコンペティションだ けでは説明し得ない異種植物間のコ ンペティションの原因であろうと考 えた。

このよらに偉い先生がいわれたの で, その後, 半世紀以上にわたって 天然に生産される阻害物質について の研究は行なわれなかった。 ところ が 1940 年代になってから,アメリ カのボーナ一派が, encelia という 砂漠の植物に阻害物質があることを 発見した. この植物は雨期に繁って， 乾期には落葉する.雨期になって注 かの植物が繁ららとすると, encelia の葉の中にある物質が土壇に溶り出 して，ほかの植物の発育を和さえる ということがわかった。 この物質は， 3-acetyl-6-methoxybenzaldehyde
である. 同じころ, guayule（ゴム タンポポ）をアアメリカが外国から 入れてその適地を探すための試験を やっていたときに，古い植物のある 培地ではこの植物の幼苗が育たない ことから調べてみると, guayule の 根からある毒物が分泌され，それが 同種の植物の生長を抑制するという ことがわかった. その毒物はtranscinnamic acid である.

農業のほうもそらいう見かたでみ れば，たくさん問題があるように思 う.現に，たとえばアメリカでク口 クルミの生垣を作っているところで, リンゴの生産が阻害されたり, トマ 卜の地上部が枯れるといら実例もあ りますし，ある作物とある作物の組 合せでは一方が影響を受けるといら ことがあるわけですね。このように 植物個体の生長・発育や，個体の間 の相互関係などをすべて物質的基礎 に立って研究すると、そのなかから 新しいケミカルコントロールの知恵 が得られると思らのです。

杉、メ科とイネ科との混播で, イネ科のほらが次第に優占していく というようなことは, コンペティシ ョンの問題もあるでしょら。混播牧 草は農業上大事なことですが，混播 率といらか, 優占度が変わってくる といらことがある.

山田 生態学のほうではアレロ パシー (allelopathy) と呼んでいま すね.

\section{作用物質の検索法を}

\section{どうするか}

\section{田村 ある1つの現象があると} き，そこに必ず何か物質的な原因が 介在しているのではないかと考㝋て みることの必要性は，私もまったく 同感です. 私は, これからケミカル コントロールの役に立つ作用のある ものを見つけていく検索方法につい ては, こう考光ています。

1 つは, 本来, 植物の中に含ま机 ていて，そしてその植物の生育ある いは生活現象一開花にしても，休 眠にしても—を調節している物質 を取り出し，その構造を決定する。 
できればさらに，それを構成するエ ッセンシャルな構造だけもった，よ り簡単なものを合成するということ だと思う。

もら 1 つは, 本来, 植物とは全然 無関係な物質を外部から与えて，植 物がそれに対してどらいら反応を示 すかを調べる方法である。

外部から物質を与える場合，ぞう いらところからその物質をもってく るかといら問題ですね.これには私 は，1つは天然物一一番手っとり 早いのは微生物の代謝産物だと思い ますが一をある植物に与えでみて， それがどらいらレスポンスを示すか を観察する。これは抗生物質のスク リーニングと同じ考え方です，あと は生理作用をもっていると尓想され るものを合成して植物に与えてみる. ところが，人間が合成する範囲は， 過去の経験，あるいは知識に支配さ れることと，もう1つには合成に時 間がかかり，あるいは，合成がむず かしいといらことで，テストする物 質の種類が限定される。これに対し て, 微生物の代謝産物を外部から与 える万法は比較的やさしいので，わ れわれ化学者からみた場合, ケミカ ルコントロールに役立つ物質を見い だしていくのに適した方法ではない かと思っている。

余談になるが，落花の問題に関連 しては, カリフォルニア大学の Addicott が，棉を落花させる作用のあ る物質を結晶にとって，構造を推定 している.また，イギリスの Wye College $の$ Wain は, イェロールー ピンで最下段にさやがつくとあとの 花やさやが落ちることから，若いさ やの中には落花作用のある物質があ るだろらということで研究を始め, すでに有効物質の単離に成功してい る.あまり機械論的に生物を考えて はいけないと思らが，少なくともそ らいら可能性を考えながら現象をみ るといら態度は, ぜひとも必要だと 思います标。

倉石 そこで今度, 生物学者の 弫らでいらと, そらいらららに出て きたものを，実際にやってみると， 試験管の中では Addicott の方法に
しても落ちるけれども, 実際の植物 では落ちないといらことが出てくる。 その場合に, なぜ落らないかという ことですが，自然においては，たま たまとれが，たとえば低温だったか ら，あるいは高温だったからきいた きかないということがあると思う。 そのためには，どらしても生物全体 についてのホルモナルなことを全部 調べあげなければならない。

もら1つ大事なことは，そういら ものを加えたときに，今までになか った違った影響が出てくる，たとえ ば肥料関係も全然違ってくると思う。 そうなると, 今までの肥料の人たら が営々としてやってきたことを，も ら一度やり直さなければならない。 そういらことがいろいろあって,ず いぶんたいへんになってくるけれど も, しかし，そらいうことを旗印に し, これから将来の農学としてやっ ていかないことには，どうにもなら ないわけですね.

\section{ロ ファイトトロンが \\ どうしても必要}

會石これはぼく自身植物を扱 ら場合，一定の条件で育てることが ぞうしても必要になる。そこで, フ アイトトロンが，どうしても必要に なってくる.これがないと，たとえ ば私のところは, グリーンの植物を 扱っているといっても, 今までの状 態では一定の条件で植物を生青させ ることがでさず, 再現性のある結果 が得られにくいので, 今後は, ある いはあきらめるよりしょらがないか もしれないと思っている。

田村 ファイトトロンで思い出 すのは, フランスの Gif-sur-Yvette にあるファイトトロンです.すばら しいと思う。ある専門家はああいら ものは馬鹿馬鹿しいといっている. しかし私は, 馬鹿馬鹿しくてもいい と思うのです、今の日本の政策の中 だと, 再軍備にはむちゃくちゃな金 を使っている。一体，今まで日本の 為政者が科学技術，ことに基礎的な 科学を発展させるために，どれだけ 無䭾な金を使ったことがあるだろら
か．無駄な金どころではなくて，必 要な金さえも出さないではないか. 無駄だといって他人のことを笑う前 に，必要なものはよこせといらこと を，われわれは声を大きくしていわ なければならないと思う。

フォイトトロンに限らず，あの周 辺には CNRS* に所属する天然物化 学研究所とか, そのほかいろいろな 国立研究所がありますが，ああいら ところへ日本の総理大臣なり, 科学 技術庁の長官が行って見てきてほし いです称。フランスの場合だと，そ のほかに農業関係で CNRA** の研 究所がベルサイ二にある，ああいら ものを見ると, フランス人の心意気 といらか,ド・ゴールを頭とするフ ランス政府の意気ごみといらか，そ らいったものに打たれます。杉さん もとらいう点から, 行政面でもぜひ 今後活躍していただかなければなり ませんね。

杉私の同僚の 1 人がいまその 辺を見て歩いています.ベルサイユ にも行っているはずですから，いい みやげ話をもってくると思います。 オランダとか, フランス, ドイッな ぞ，全部陸続きの国ですから，われ われの感じでは名古屋か大阪に行く ようなつもりで，よその国を歩きま われるというのはいいですね. 日本 政府の要路の人も，何か特別の目的 をもっていればとにかく，ああいら ふらに近ければ，行きずりにでもひ ょいと見ることができるでしょら。

田村 最後に夢物語, 抱負みた いなことを皆さんに $1 つ$ 話しいた だけたらと思います。また，こんな ことを，きょら話しておく必要があ ったといら点があれば，それを補っ ていただいても結構です。

\section{【組織的な活動のために 共通の場を作ろう}

杉先ほどちょっとふれました けれども, 新しい研究が開けてくる

* Centre National de la Recherche Scientifique

** Centre National de la Rccherche Agronomique 
気運があるわけですから，私は農芸 化学とか, 植物とか, 作物とかいら

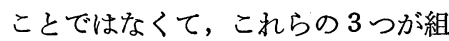
織活動をすることがまず第 1 かと思 います，六れも共通の場を根っこに おいてといらことですね.このよう な組織活動が，いつもあるというよ らなことが望ましいですね.

倉石たと学ば人が集まるだけ なら，今でもそれはできます、けれ ぞも，いま私がこういっていても， 研究室に帰ったら，それができない わけですそそれができるようなとこ ろまでもっていきたいと思う。

田村 まさにそのと和りで，施 設があれば，それは同時に専門的な ディスカッションができる共通の場 所ともなり得る.

その㴗かこういうこともあると 思う．たと党ば，さっきは植物学と 農学の遊離, あるいは基礎と応用の 遊離の問題が出たが, 違った面から 考えると, 生物学者は化学をやりた がらないし, 化学者は生物学に対す る興味をもたないといらことがある。 ことに応用化学者となると, 生物が 応用科学の中でどらいう位置を占め るのかわからない.われわれ農芸化 学者でも，農業生産の場でわれわれ が活動しらる, あるいは活動しなけ ればならぬ面が注んとらにあるのか どらかといらことに対する認識がき わめてらすいと思う。ですから，そ らいら問題を共通のものとするため に, 化学者は生物学に, 生物学者は
化学にもっと関心を奇せる必要があ る. そしてまた，基礎の人は応用に， 応用の人は基礎に注目して，拈互い に共通の研究の場を作るようにしな ケればならないのじゃないか。

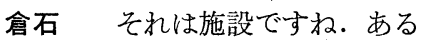
いは人員の実際の交流が大事だと思 います补，早い話が，植物の人は実 際問題として農林省にはいれないよ うな形になっている. 公務員試験と いら形で.......

杉今の公務員試験制度がこう いらことを根本的に阻害している面 がないとはい亲ませんね。

\section{農業の近代化は} 研究組織の近代化から

田村 昔から，セクショナリズ ムをつぶさなければならぬというこ とがいわれているけれども, そのセ クショナリズムが自分のことになる と非常にこわしにくいわけです. 結 局, これは社会的な場の中にお打る 人間関係の問題だと思うけれども， 日本というところは，それがすこぶ るまずいですね.

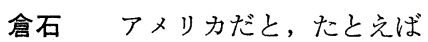
あるテーマのもとにみんなでやると いら考方方があるけれぞも，日本の 場合は, もちろん 1 人 1 人の人が学 問の自由と拐っしゃることもいいけ れども，それが研究を分散化してい るということをつくづく感じますね. もちろん学問の自由は大事だけれど
も，また同時に，よりよきものを作 ることがもっと大事だということも いえると思う。

杉こういう時代になると，新 しい分野の開拓などは，個人ではど らにもならないのではないでしょう か. 各分野の研究の間の活発なュミ ュニケーションが, 今日ほど必要な ことはないと思います．狭いカラに しがみついているようなことは，す でに遠い過去のものでしょう。

山田この座談会をこれだけに 終わらせないで，ときどき，せめて 招互いに集まってみてはどうでしょ らか。皇らいら形にもっていくため の 1 つの核として, この座談会が役 立つよらにしていこうじゃないです か.

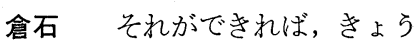
の座談会は大きな功績, 収穫があっ たということになりますね。

杉 1 つの役所の中, 学校の中 といらと, やりにくいけれども，そ らいう関係のないところでやってい くのも，1つのとっかかりになる。 農業の近代化をはかるにも, それを 研究する側の近代化なくしては道は 遠いのじゃないでしょうか。人間関 係の近代化，構造改善ですね。

田村 まさに人間関係の近代化 ですね.きょうはこれで........ 拈い そがしいところをどうもありがとう ございました。

\section{正誤表}

誤

Vol. 3 , No. 1
p. 39 (左) 上から 10 行
p. 44 脚注 11 ) 2 行
" " 13 ) 5 行
p. 45 (左) 上から 2 行
" (右) 下から 3 行
p. 46 文献 (左)
" " (右)

Vol. 3, No. 2

p. 2 見出し

" (左)上から 12 行

p. 14 第 3 図 (写真)

p. 39 (右) 上から 9 10 行

\begin{tabular}{ll} 
繁 雑 & 煩 雑 \\
モリブデン酸アンモニウム & モリブデン酸ナトリウム \\
& \multicolumn{1}{l}{ " }
\end{tabular}

\section{繁 森}

不安定でありる.

経時間に

Osmond, F. (1887). Bull. soc. Chim. Paris,
正

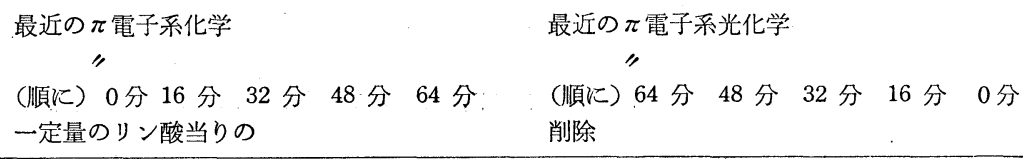

おことわり：連載講座, 核酸の分離・定量 II. 都合により次号に掲載いたします.あしからず御了承ください. 